Красинский Владислав Вячеславович доктор юридических наук, профессор кафедры уголовного права Голицынского пограничного института, полковник

Абалов Илья Юрьевич кандидат социологических наук

Красинский В.В., Абалов И.Ю. Оценка будущих террористических угроз // Современное право. 2015. № 9. С. 143-148.

\title{
Оценка будущих террористических угроз
}

В условиях формирования новых геополитических реалий, усиления военно-политической напряженности в ряде регионов мира, распространения радикальных идеологических концепций происходит трансформация терроризма и возрастает уровень террористических угроз.

Учитывая повышенную общественную опасность террористических проявлений, их транснациональный характер, конспирацию и организованность, основой конструктивного сотрудничества международных организаций, правоохранительных органов и спецслужб в сфере противодействия терроризму должно стать единое понимание террористических угроз и повышение эффективности международного и региональных механизмов контртеррористического сотрудничества.

Основополагающими элементами данных механизмов выступают формулирование государствами-партнерами будущих террористических угроз, их обсуждение и выработка единого подхода к оценке данных угроз, что позволит внести весомый вклад в дальнейшее совершенствование общей доктрины противодействия терроризму и будет способствовать поступательному наращиванию единого контртеррористического потенциала.

В краткосрочной и среднесрочной перспективе реальными угрозами террористического характера будут являться: 
1. Угроза распространения террористической активности на Ближнем Востоке и в Северной Африке.

Вооруженный конфликт в Сирии активизировал террористические силы на всем Ближнем Востоке. В ряды террористического бандподполья вливаются новые адепты радикального ислама из стран Европы, Центральной Азии и Закавказья. После предварительного обучения в специализированных тренировочных лагерях боевики активно втягиваются в организованную террористическую деятельность и боевые действия против правительственных сил.

В настоящее время и в среднесрочной перспективе основными центрами террористической активности в мире будут являться Афганопакистанская зона, Ближневосточный регион (в первую очередь Сирия и Ирак), а также Северная Африка. Геополитические процессы в Северной Африке и на Ближнем Востоке способствовали эскалации террористических проявлений, распространению экстремистской идеологии, a также активизации региональных террористических группировок. Так, расширяется география вооруженных вылазок в Северной Африке. Фиксируется миграция боевиков в центральные и южные районы континента при поддержке «АльКаиды в странах исламского Магриба», «Движения за единобожие и джихад в Западной Африке», нигерийской «Боко Харам» и сомалийской «Аль-Шабаб аль-Муджахедин» ${ }^{1}$.

Некоторые страны в этом регионе превратились в эпицентры международного терроризма. Территории отдельных государств, в т. ч. за пределами региона, опосредованно используются как дополнительный ресурс для вербовки боевиков и организации финансово-экономической подпитки под предлогом благотворительной деятельности. Новые разноплановые угрозы терроризма проявятся в Сахаро-Сахеле, Сирии и

\footnotetext{
${ }^{1}$ Стратегия террора ИГИЛ [Электронный ресурс] Режим доступа: http://www.voprosik.net/strategiya-terrora-igil/ (дата обращения 22.05.2015).
} 
граничащих с ней государствах, зоне Африканского рога, Алжире, Ливии, Мали и Нигерии ${ }^{2}$.

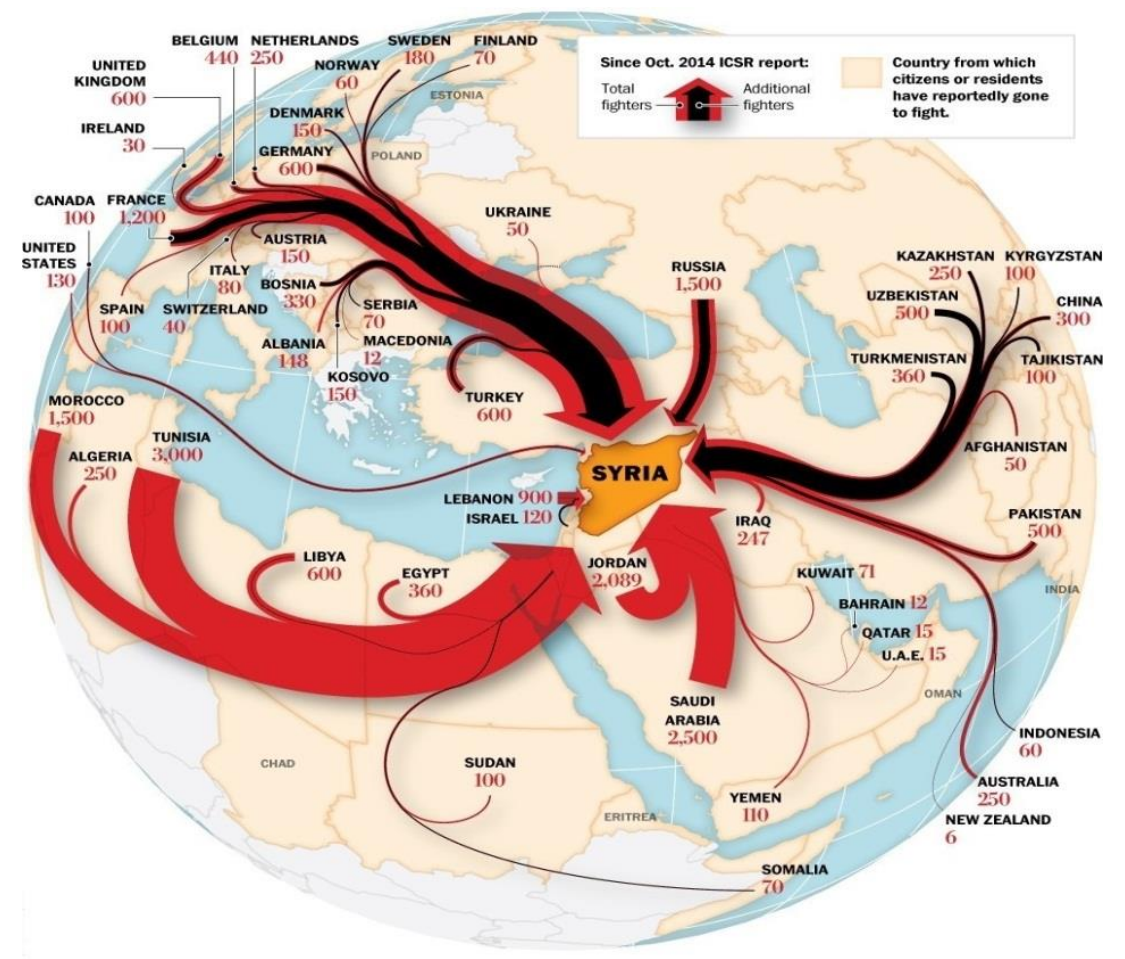

Рис. 1. Распространение террористической активности на Ближнем Востоке и в Северной Африке ${ }^{3}$.

2. Угроза участия международных террористических организациий во внутренних конфликтах суверенных государств, способствующая размыванию границ между международным и внутренним терроризмом и усилению их влияния на социчально-политическую обстановку в других странах.

В настоящее время «Аль-Каида», «Исламское государство» и другие международные террористические организации продолжают объединение под своей эгидой региональных и локальных террористических структур, нацеленных на борьбу со светскими государствами, в т. ч. путем нанесения им максимального экономического ущерба. Их усилия направлены на

${ }^{2}$ ИГИЛ - не религиозная организация [Электронный ресурс] Режим доступа: http://www.islamsng.com/kgz/report/8608. (дата обращения 06.05.2015).

${ }^{3}$ Foreign fighter total in Syria/Iraq now exceeds 20,000; surpasses Afghanistan conflict in the 1980's [Электронный ресурс] Режим доступа: http://icsr.info/2015/01/foreign-fightertotal-syriairaq-now-exceeds-20000-surpasses-afghanistan-conflict-1980s/ (дата обращения 04.03.2015). 
разжигание локальных конфликтов в регионах и странах с мусульманским населением ${ }^{4}$.

Прямую угрозу международной безопасности представляет участие граждан различных государств во внутренних вооруженных конфликтах на стороне международных террористических организаций. Данная проблема приобрела трансграничный характер и требует принятия неотложных мер как на национальном, так и на международном уровне.

3. Возвращуение в страны исхода боевиков, обладающчих опытом проведения террористических акиий.

Перспектива возвращения из регионов с повышенной террористической активностью боевиков в страны исхода и проведения ими террористических актов представляет существенную опасность в ближне- и среднесрочной перспективе. Вернувшиеся боевики отличаются не только радикальными взглядами и идеями (по сравнению с периодом, предшествовавшим их отъезду), они обладают навыками обращения со стрелковым оружием и изготовления взрывных устройств, знанием тактических приемов ведения боевых действий, в т. ч. в городских условиях, и многочисленными связями в криминальной среде. Кроме того, данная категория лиц продолжит играть роль идейных проводников исламистского радикализма и будет участвовать в подстрекательстве и вербовке боевиков для террористической деятельности в зонах вооруженных конфликтов 5 .

Co стороны международных террористических организаций проводится целенаправленная работа по рекрутированию и направлению сторонников экстремистских взглядов в лагеря подготовки боевиков в целях их последующего использования в международной террористической деятельности. После прохождения подготовки боевики направляются в террористические группировки, действующие в т. н. горячих точках. При

${ }^{4}$ См., например: Меркурьев В. В., Агапов П. В. «Исламское государство Ирака и Леванта» (ИГИЛ) в системе угроз национальной безопасности России // Информационный бюллетень АТЦ СНГ, 2014. № 23. С. 55-56.

${ }^{5}$ Стратегия террора ИГИЛ [Электронный ресурс] Режим доступа: http://www.voprosik.net/strategiya-terrora-igil/ (дата обращения 22.05.2015). 
этом основной целью рекрутирования указанной категории лиц, помимо участия в боевых действиях является их последующее использование для распространения религиозно-экстремистской идеологии, проведения вербовочной работы и организации террористической деятельности в других странах 6 .

4. Повыщение информационной составляющей террористической деятельности, стремительное развитие террористическими организациями информациионо-пропагандистской инфраструктуры и использование в противоправных цуелях современных информационно-коммуникационных технологий.

В настоящее время в глобальной информационной сети функционируют сайты практически всех международных террористических организаций, материалы террористической направленности публикуются более чем на сорока языках мира. В результате активной деятельности прежде всего приверженцев радикального ислама, сложилась всемирная система интернет-ресурсов, ориентированных на религиозноидеологическую подготовку будущих членов террористического подполья. Основными направлениями заранее спланированной террористической деятельности в сети Интернет являются: информационное сопровождение противоправных акций террористических группировок, в т. ч. демонстрация их силы и возможностей; поддержание связи между субъектами террористской деятельности; пополнение социальной базы терроризма; обучение и идеологическая обработка террористов; сбор средств для финансирования собственной деятельности ${ }^{7}$.

5. Попытки проникновения террористических сил в общественнополитические движения, органы государственной власти и местного самоуправления.

${ }^{6}$ См., например: Поздняков А. И. Транснациональный терроризм как средство геополитики // Вестник Национального антитеррористического комитета. 2014. № 2(11). C. 95-103.

Яшлавский А. Терроризм в сети - и в сетях экстремизма // ФСБ: за и против. 2015. № 1(35). C. 9. 
Ряд террористических организаций осуществляют вербовочные подходы к представителям органов государственной власти, управления и силовых структур, в т. ч. через членов их семей. Проникновение в органы власти и местного самоуправления террористических сил влечет за собой их радикализацию, выдвижение должностными лицами экстремистских требований, а также используется как средство легитимизации и политического прикрытия террористической деятельности. Кроме того, будут продолжаться попытки инфильтрации террористов в существующие общественно-политические движения, а также создания ими самостоятельных организационных структур, представляющих опасность как для конкретных социальных (этнических, религиозных) групп, так и для государства в целом.

Кроме того, в настоящий момент сформировались тенденщии, определяющие содержание существующих $и$ будущих угроз террористического характера:

1. Рост общественной опасности терроризма как на национальном, так и на международном уровне, обусловленный все более широким и активным использованием террористами особо опасных форм и методов, сил и средств террористической деятельности, значительно повышающих угрозу человеческих потерь и материального ущерба при совершении террористических актов.

2. Расширение в ряде регионов сочиальной базы терроризма, вызванное заметным ростом вовлеченности в общественно-политическую деятельность и радикальные течения значительного числа представителей различных социальных групп, особенно в социально неблагополучных регионах, в странах, переживающих тяжелые процессы социальной, экономической и политической модернизации.

3. Повыщение уровня организации субъектов терроризма, выраженное в создании относительно устойчивых, долговременных террористических структур различной идейно-политической направленности, наличии 
разработанных теорий и концепций их деятельности. Многие террористические организации располагают современными системами связи, вооружения, стабильными источниками финансовой и материальнотехнической поддержки.

Для организации активно действующих террористических структур характерны четкая внутренняя дифференциация, наличие целого ряда специализированных звеньев центрального и регионального управления, в т. ч. отвечающих за материально-техническое обеспечение, финансирование, пропаганду и обеспечение собственной безопасности. Это способствует совершенствованию организации террористических структур, повышению террористического потенциала и мобильности ${ }^{8}$.

4. Развитие связей между террористическими структурами как в рамках отдельных стран, так и в международном масштабе приведет к созданию устойчивых блоков этих организаций.

В среднесрочной перспективе продолжится укрепление связей между террористическими структурами, близкими или одинаковыми по своей идейно-политической направленности, в современных условиях, особенно между структурами, созданными на национал-экстремистской и исламскофундаменталистской основе. Характерными формами их взаимодействия будут являться: обмен информацией; согласование задач; оказание помощи в людской силе, в обучении боевиков; проведение совместных или согласованных террористических акций.

5. Взаимопроникновение (соединение) террористических и иньх форм политического насилия, сопровождаемое значительными изменениями в организации террористических структур, что выражается в увеличении их численности, расширении арсенала средств насильственной деятельности, изменении тактики, увеличении масштабов преступной деятельности.

\footnotetext{
${ }^{8}$ См., например: Cmепанова $E$. Основные тенденции в области современного терроризма: регионализация вооруженных радикально-исламистских движений на примере ИГИЛ // Индекс безопасности. 2014, № 4 (111). С. 52.
} 
В ряде регионов мира наблюдается сращивание преступной деятельности террористических организаций с политически мотивированной вооруженной борьбой9

Данная тенденция отражает изменения в стратегической направленности действий этих организаций, прежде всего в их стремлении взять под свой контроль части территории отдельных государств, не допустить деятельности законных органов власти и сформировать собственные, отторгнуть определенные территории.

6. Смыкание террористических структур с организованной преступностью, обусловленное совпадением их целей и задач.

Террористические организации могут быть втянуты в деятельность структур организованной преступности, а последние нередко прибегают к использованию форм и методов терроризма. Основой взаимодействия структур терроризма и организованной преступности остается их сотрудничество в сфере незаконного оборота оружия и наркотиков, торговли людьми, контрабанды, совершения иных тяжких преступлений.

В складывающихся условиях необходимо максимально использовать партнерский потенциал международных организаций, спецслужб и правоохранительных органов для выработки адекватных мер реагирования, направленных на нейтрализацию будущих угроз террористического характера.

Решение данной задачи требует выработки комплексного подхода и консолидации усилий органов власти, силовых структур, религиозных и общественных организаций, средств массовой информации.

${ }^{9}$ См., например: Володина Н. В. Деятельность «Исламского государства» («ИГ») как угроза конституционной безопасности России // Российский следователь. 2015. № 3. C. 44 . 